\title{
The effect of clay content on the relation between uniaxial compressive strength and needle penetration index for clay-bearing rocks
}

\author{
Sair Kahraman ${ }^{*}$, A. Sercan Aloglu ${ }^{2}$ Egemen Saygin ${ }^{1}$ and Bilal Aydin ${ }^{1}$
}

*Correspondence:

sairkahraman@yahoo.com

${ }^{1}$ Mining Engineering

Department, Hacettepe

University, Ankara, Turkey

Full list of author information

is available at the end of the

article

\begin{abstract}
The needle penetration index (NPI) test is a non-destructive test that is applicable both in the field and laboratory, and does not require any special sample preparation. This test has been used for the estimation of physico-mechanical properties of soft rocks. In this study, the influence of the clay content on the relation between uniaxial compressive strength (UCS) and the NPI has been investigated for some clay-bearing rocks. The needle penetration tests were carried out at nine different gallery faces during the Cayirhan Coal Mine excavations, and the NPI values were calculated. Claystone, clayey limestone and clay blocks were collected from the locations on which the NPI tests were performed for the determination of rock strength and clay contents. The clay contents and clay fractions of the samples were determined using XRD analysis. A strong correlation has been found between the UCS and the NPI, but some of the data points were scattered. Strong correlations were also found between the NPI and both the total clay content and the smectite content. The UCS values were also strongly correlated to the total clay content and the smectite content. A multiple regression analysis was performed to determine the influence of clay content on the UCS-NPI relation and a very strong model was derived. The correlation coefficient of the multiple regression model is fairly higher than that of the UCS-NPI relation derived by using simple regression analysis. Concluding remark is that the clay content significantly affects the UCS-NPI relation in clay-bearing rocks.
\end{abstract}

Keywords: Uniaxial compressive strength, Needle penetration index, Clay content, Clay-bearing rocks

\section{Introduction}

The uniaxial compressive strength (UCS) of rock is used for designing surface and underground structures constructed in rock mass. Smooth core samples suggested by standards for the UCS tests cannot always be prepared, particularly, from weak and clay-bearing rocks. Some simple indirect test methods such as point load test and block punch index tests have been developed to estimate the mechanical properties of rocks. However, the specimen preparation from weak and clay-bearing rocks is still difficult for these indirect

(c) The Author(s) 2021. This article is licensed under a Creative Commons Attribution 40 International License, which permits use, sharing adaptation, distribution and reproduction in any medium or format, as long as you give appropriate credit to the original author(s) and the source, provide a link to the Creative Commons licence, and indicate if changes were made. The images or other third party material in this article are included in the article's Creative Commons licence, unless indicated otherwise in a credit line to the material. If material is not included in the article's Creative Commons licence and your intended use is not permitted by statutory regulation or exceeds the permitted use, you will need to obtain permission directly from the copyright holder. To view a copy of this licence, visit http://creativeco mmons.org/licenses/by/4.0/. 
tests. In order to bridge this gap, the needle penetration index (NPI) test, which is a simple and a practical test, was developed.

The needle penetration test is a non-destructive index test which is applicable both in the field and laboratory and does not require any special sample preparation [1]. This test has been used for the estimation of physical and mechanical properties of weak or soft rocks [2-8]. However, data points in the correlation plots are highly scattered as stated by ISRM [1]. The scattering of the data may stem from the clay content of the clay-bearing rocks. The aim of this study is to investigate the effect of clay content on the UCS-NPI relation for claybearing rocks.

\section{Previous studies}

The needle penetrometer was developed in Japan and launched as a suggested method by the Rock Mechanics Committee of the Japan Society of Civil Engineers [9] for the situations where core sampling is difficult or not possible. The NPI test is primarily used for the estimation of the UCS of soft and weak rocks [2-6, 9-13].

Okada et al. [10] carried out the NPI and the UCS tests on mudstone and artificial cement-based samples and derived the following equation:

$$
\log U C S=0.978 \log N P I+1.599
$$

where UCS is the uniaxial compressive strength $\left(\mathrm{kgf} / \mathrm{cm}^{2}\right)$ and NPI is the needle penetration index $(\mathrm{kgf} / \mathrm{mm})$.

Yamaguchi et al. [2] tested coarse grained soft rocks mainly composed of pyroclastic flow and fall deposits and derived the following equation for the prediction of the UCS from the NPI:

$$
\log U C S=0.982 \log N P I-0.209
$$

where UCS is the uniaxial compressive strength $\left(\mathrm{kgf} / \mathrm{cm}^{2}\right)$ and NPI is the needle penetration index $(\mathrm{kgf} / \mathrm{cm})$.

Takahashi et al. [14] conducted the NPI and the UCS tests on sandstone, mudstone, conglomerate, greywacke and tuff samples, and developed the following equation:

$$
U C S=1.5395 \log N P I^{0.9896}
$$

where UCS is the uniaxial compressive strength $(\mathrm{MPa})$ and NPI is the needle penetration index $(\mathrm{N} / \mathrm{mm})$.

Uchida et al. [12] performed the NPI and the UCS tests on sandstone and derived the following equation for the estimation of the UCS:

$$
U C S=27.3 N P I+132
$$

where UCS is the uniaxial compressive strength $(\mathrm{kPa})$ and NPI is the needle penetration index $(\mathrm{N} / \mathrm{cm})$.

Maruto Co. Ltd. [15] which produced the needle penetrometer suggested the following empirical equation:

$$
\log U C S=0.978 \log N P I+2.621
$$


where UCS is the uniaxial compressive strength $\left(\mathrm{kN} / \mathrm{m}^{2}\right)$ and NPI is the needle penetration index $(\mathrm{N} / \mathrm{mm})$.

Park et al. [5] used artificial rock samples mixed with cement and bentonite to develop a relation between the UCS and the NPI. The derived relation is as follows:

$$
U C S=0.05+0.040 N P I-0.0001 N P I^{2}
$$

where UCS is the uniaxial compressive strength (MPa) and NPI is the needle penetration index $(\mathrm{N} / \mathrm{mm})$.

Ulusay and Erguler [13] evaluated a database consisting of a total of 725 data points from the previous studies and additional new tests, and suggested the following equation:

$$
U C S=0.4 N P I^{0.929}
$$

where UCS is the uniaxial compressive strength $(\mathrm{MPa})$ and NPI is the needle penetration index $(\mathrm{N} / \mathrm{mm})$.

Aydan [6] evaluated the data of soft rocks from Japan, Turkey, and Egypt to infer the physico-mechanical properties in terms of the NPI, and found the following relation between the UCS and NPI:

$$
U C S=0.2 N P I
$$

Aydan and Ulusay [7] evaluated the geomechanical properties of Derinkuyu antique underground city, and derived the following relation for Derinkuyu tuff:

$$
U C S=0.3 N P I
$$

Kahraman et al. [16] investigated the predictability of physico-mechanical properties of Erciyes pyroclastic rocks from the NPI, and developed the following relation between UCS and NPI:

$$
U C S=0.16 N P I
$$

Kahraman et al. [17] investigated the predictability of coal strength from the needle penetration test and stated that coal strength can be predicted from the NPI. They derived the following relation between UCS and NPI for coal:

$$
U C S=0.35 P I
$$

Heidari et al. [18] performed the NPI tests on sedimentary rocks including gypsum, marl, siltstone and sandstone to study the reliability of the NPI test for the prediction of the UCS, and derived the following equation:

$$
U C S=0.6715 N P I-10.075
$$

Rahimi et al. [19] investigated the predictability of the UCS of gypsum rocks from the NPI. They derived the following equations:

For dry samples 


$$
U C S=0.49 N P I
$$

For dry samples

$$
U C S=0.56 N P I
$$

Ulusay and Erguler [13] compared the data from the six different study and showed that the data of Yamaguchi et al. [2] and Takahashi et al. [14] show different trends from the data of the other researchers. They stated that the mentioned data obtained from conglomerates and pyroclastic rocks, and probably might have been affected from grain crushing. They also indicated that the prediction curves of the data of other four studies tend to separate from each other for the UCS values greater than $5 \mathrm{MPa}$ and the relative differences between them increases as the UCS increases. Ulusay and Erguler [13] recommends that the use of the NPI on the rock types consisting of coarse grains embedded in a cementing material, such as conglomerate, breccia etc. should be avoided. The NPI test should be limited to infer the properties of the soft matrix for the rocks consisting of coarse hard grains embedded in a cementing material [1].

Aydan [6] demonstrated that the conversion factor for the UCS-NPI relation ranges between 0.06 and 0.7 , and most of data points were clustered around the empirical function with a coefficient of 0.2 . He stated that the conversion factor for the UCS-NPI relation should be evaluated for each rock group separately, in order to improve the correlations.

The UCS-NPI correlations suggested by several researchers differ from each other. As explained above, this is thought to be due to coarse grained rocks. Some other properties of rocks such as clay content may also influence the UCS-NPI correlations.

\section{Geology and sampling}

The needle penetration tests were carried out at nine different gallery faces during the Cayirhan Coal Mine excavations. This study was carried out in the Cayirhan Lignite Mine located in Cayirhan Town of Nallihan County, $122 \mathrm{~km}$ west of Ankara (Turkey). Cayirhan coal basin is formed by old Miocene series called M1, M2, M3, and M4 and Pliocene formation (Fig. 1). Coal seams are located in the M1 formation, which is approximately $4 \mathrm{~km}$ wide, and approximately $25 \mathrm{~km}$ long in the south-west to northeast direction. There is a light-brown-coloured limestone layer of 5-6 $\mathrm{m}$ thickness over the coal seams and 7-8 m thickness green-coloured clay-stone layer below the seams. Under the clay-stone there is a 15-20 m thick layer of volcanic breccia. Moreover, a third coal seam is found 140-160 m below the workable seams. The M2 formation consists of clay and marl at a thickness of $80-120 \mathrm{~m}$. There are two bituminous schist layers of $20 \mathrm{~m}$ at the top and bottom of the M2 formation. Further, M3 is the hardest formation composed of beige-coloured siliceous limestone and has a thickness of about 30-35 m. This is the major aquifer zone in the field. Many cavities and fractures at the bottom levels are enabling collection of water. Majority of the area is covered with M4 formation composed of grey, red, green, and beige tuffs. Despite their hard structure, they get broken into parts when subjected to water. Therefore, $15-20 \mathrm{~cm}$ of a clastic portion covers the surface. The thickness of this formation is 


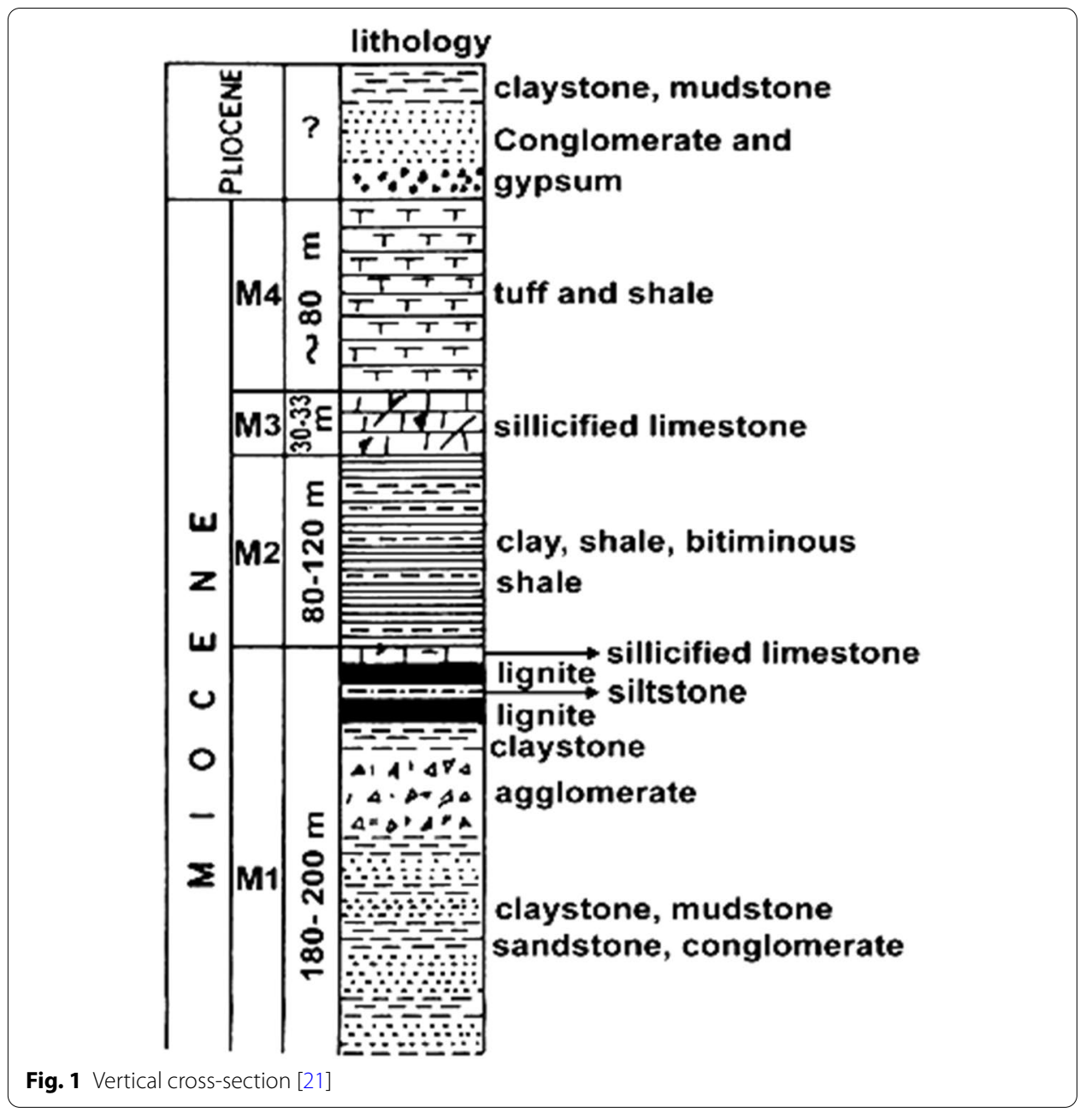

about $80 \mathrm{~m}$ and consists of silica $5-10 \mathrm{~cm}$ at the bottom layers. The two main normal faults, the Davutoglan fault and the North fault in the north-west and south-east directions, respectively, are almost parallel and are about $1.5-2 \mathrm{~km}$ apart from each other [20].

The block samples of rocks were collected from the locations where needle penetration tests have been performed for laboratory tests. The sampling locations and rock types are given in Table 1.

\section{Mineralogy}

In order to determine the relative quantity of clay minerals and whole sample mineralogy, X-ray diffraction (XRD) analyses has been performed on the samples. The XRD diffractograms were obtained at Hacettepe University X-ray Micro-analysis Laboratory using a Philips PW-1140 model diffractometer. From the powder diffractograms, the semi-quantitative estimates of the minerals were determined. The XRD results are shown in Table 2. The percentages of clay minerals in the samples range from 12 to $76 \%$. Montmorillonite is generally the main clay mineral. 
Table 1 Sampling locations and rock types

\begin{tabular}{lll}
\hline Rock code & Location & Rock type \\
\hline 1 & D $310-142 \mathrm{~m}$ & Claystone \\
2 & D $310-143.5 \mathrm{~m}$ & Claystone \\
3 & G East $101.75 \mathrm{~m}$ & Clay \\
4 & G East $102.5 \mathrm{~m}$ & Clay \\
5 & E 209-104 m & Clay \\
6 & D 310-302.5 m & Claystone \\
7 & D 310-304 m & Claystone \\
8 & G East $201.5 \mathrm{~m}$ & Clay \\
9 & D 310-280 m & Clayey limestone \\
\hline
\end{tabular}

\section{The needle penetration test}

A needle penetrometer has been developed by MARUTO Co., Japan, to estimate the UCS of soft rocks. It is a lightweight portable device with a weight of about $700 \mathrm{~g}$ (Fig. 2). The needle is made up of hardened steel and consists of a 0.84-mm-diameter rod terminated by a conical tip. The device mainly consists of a presser, a chuck, a penetration scale $(0-10 \mathrm{~mm}, 1 \mathrm{~mm}$ graduation), a load scale $(0-100 \mathrm{~N}, 10 \mathrm{~N}$ graduation), a load indicator ring, a cap (removable; spare penetration needles contained in the grip), a penetration needle and a spring mounted in the penetrometer grip [1].

The needle of the penetrometer is pushed into the rock until $100 \mathrm{~N}$ force is reached and the penetration depth is measured from the position of the presser on the penetration scale. There is a probability that the maximum penetration depth $(10 \mathrm{~mm})$ may be attained for softer and saturated rocks before the maximum penetration force is reached. In this case, the test stops at this depth, the penetration load is read from the load scale, and the NPI is calculated from the following equations [1]:

$$
\begin{aligned}
& \text { For } \mathrm{F}=100 \mathrm{~N} \text { and } \mathrm{D} \leq 10 \mathrm{mmNPI}=100 / \mathrm{D} \\
& \text { For } \mathrm{D}=10 \mathrm{~mm} \text { and } \mathrm{F} \leq 100 \mathrm{NNPI}=\mathrm{F} / 10
\end{aligned}
$$

where NPI is the needle penetration index $(\mathrm{N} / \mathrm{mm}), \mathrm{F}$ is the applied load $(\mathrm{N})$, and D is the depth of penetration $(\mathrm{mm})$.

The needle penetration tests were carried out at least 10 times at the nine different gallery faces (Fig. 3) during the excavations in Cayirhan Coal Mine, and the NPI values were averaged (Table 3 ).

\section{Point load test}

Since the rock samples were weak, core samples could not be prepared for the UCS test. For this reason, the point load tests were selected for the strength test. Prismatic test specimens were prepared from the rock blocks by dry cutting them with a diamond saw (Fig. 4a). Some of the samples that failed in the point load tests are indicated in Fig. 4b. After the tests, point load index values were calculated and converted to the UCS values by multiplying them with the conversion factor of 22 , as 


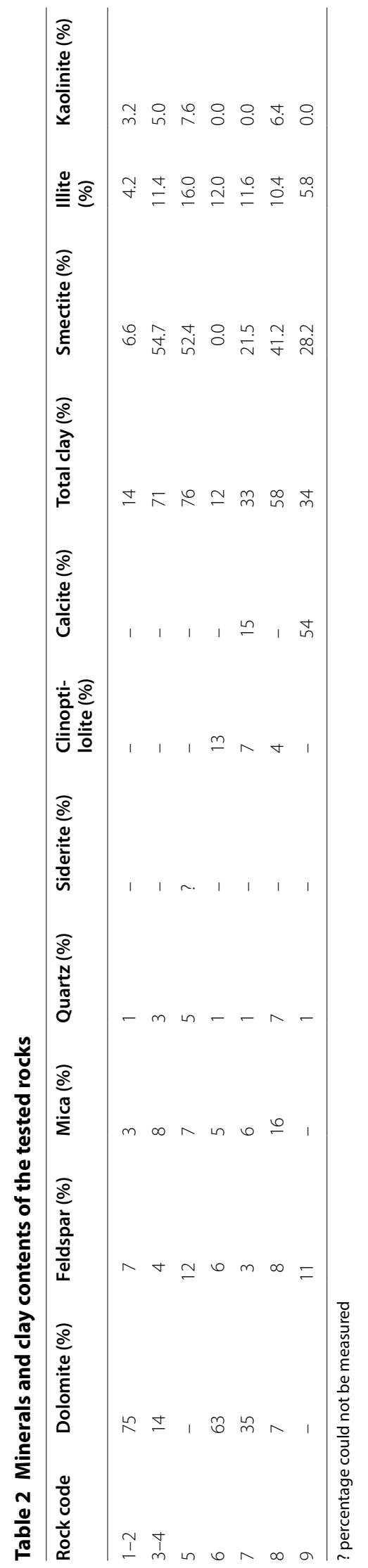




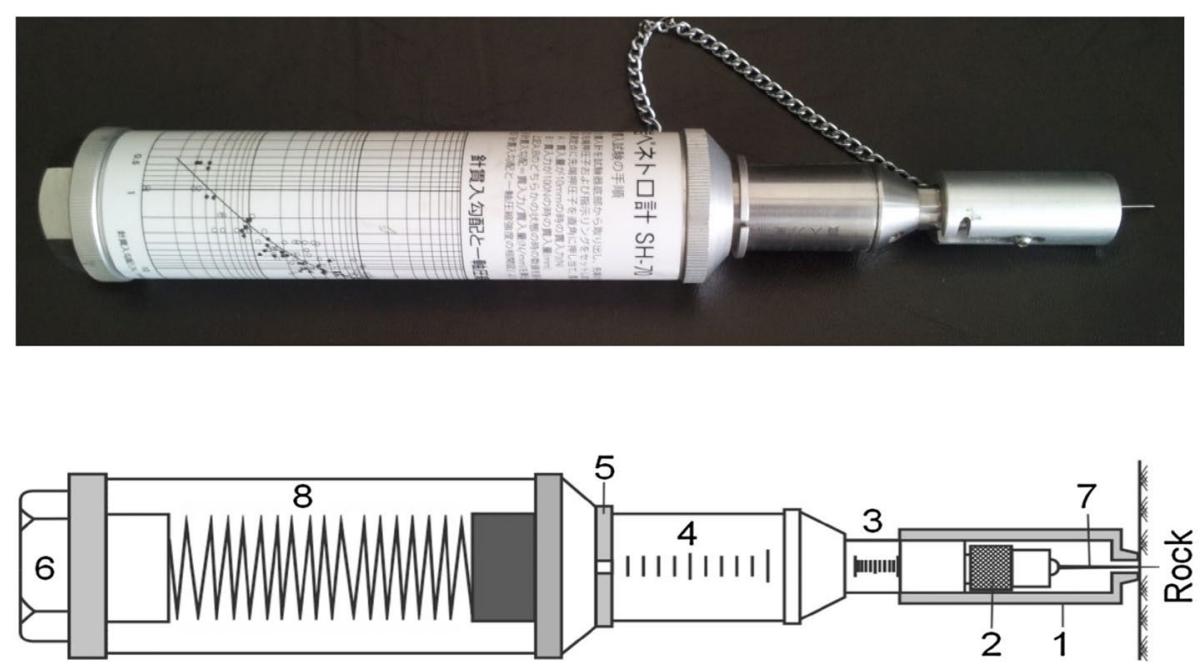

Fig. 2 Needle penetrometer and its parts: (1) presser, (2) chuck, (3) penetration scale, (4) load scale, (5) load-indicating ring, (6) cap, (7) penetration needle, and (8) spring [1]

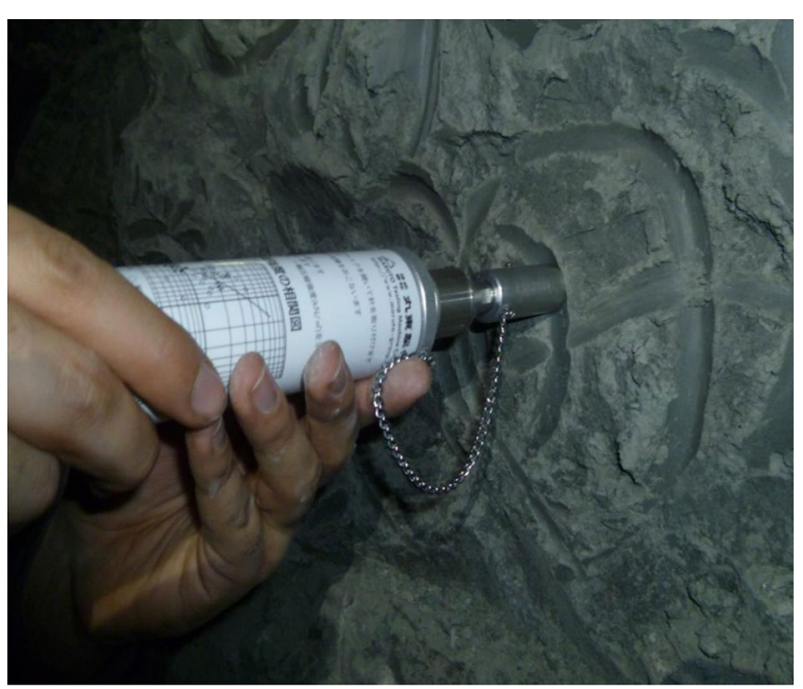

Fig. 3 Performing needle penetration test at the gallery face

suggested by ISRM [22]. The results of the tests and the estimated UCS values are given in Table 3.

\section{Results and discussion}

First, the UCS-NPI relation was investigated. There is a strong correlation between the two parameters, as shown in Fig. 5. The equation of the correlation is as follows:

$$
U C S=0.35 N P I \quad \mathrm{r}=0.84
$$


Table 3 Needle penetration index, point load index and estimated uniaxial compressive strength values

\begin{tabular}{llll}
\hline Rock code & $\begin{array}{l}\text { Needle penetration index } \\
(\mathbf{N} / \mathbf{m m})\end{array}$ & Point load index (MPa) & $\begin{array}{l}\text { Estimated uniaxial } \\
\text { compressive strength } \\
(\mathbf{M P a})\end{array}$ \\
\hline 1 & & 1.40 & 30.8 \\
2 & 87.5 & 1.40 & 30.8 \\
3 & 71.5 & 0.10 & 2.3 \\
4 & 6.2 & 0.16 & 3.5 \\
5 & 7.1 & 0.44 & 9.6 \\
6 & 55.1 & 1.56 & 34.3 \\
7 & 75.3 & 0.64 & 14.1 \\
8 & 65.8 & 0.33 & 7.3 \\
9 & 4.6 & 0.74 & 16.4 \\
\hline
\end{tabular}

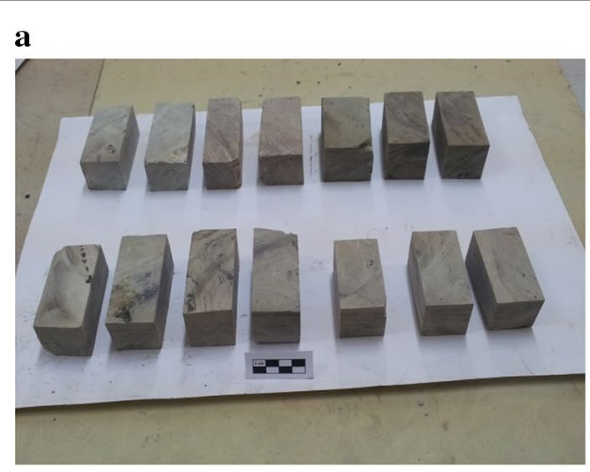

b

Fig. 4 a Test specimens for point load test, and $\mathbf{b}$ few failed samples

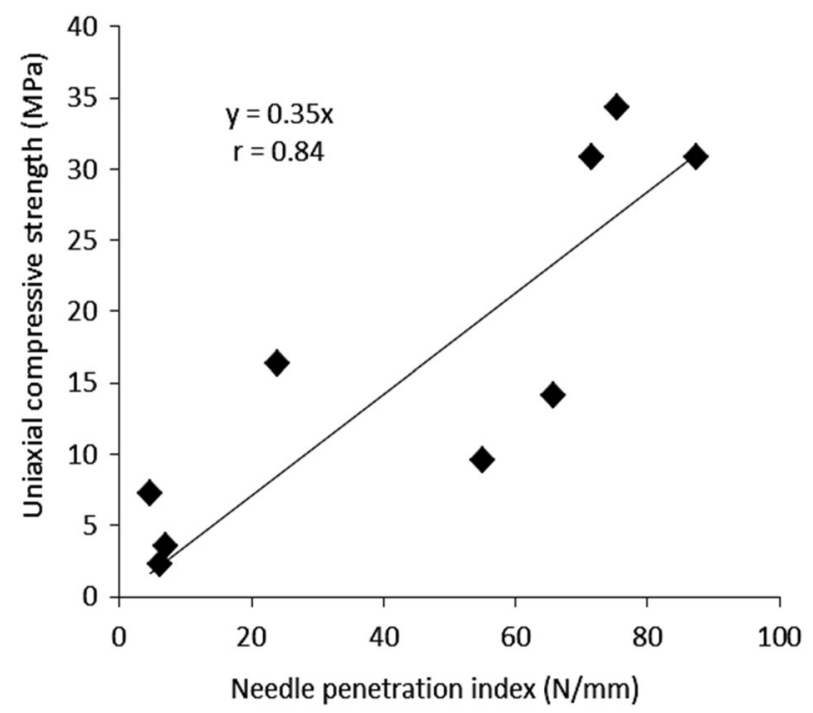

Fig. 5 Correlation between the UCS and the NPI 


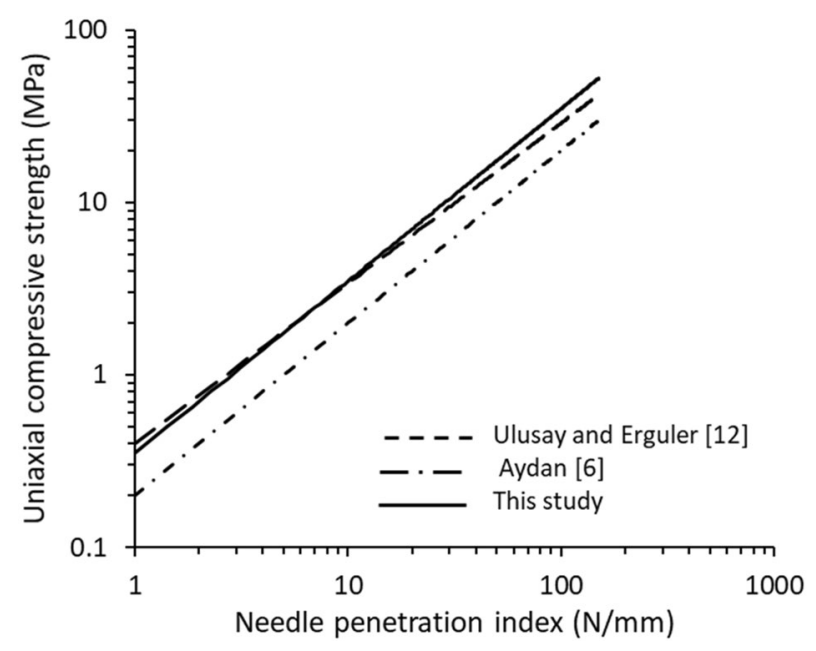

Fig. 6 Comparison between Eq. (17) and literature

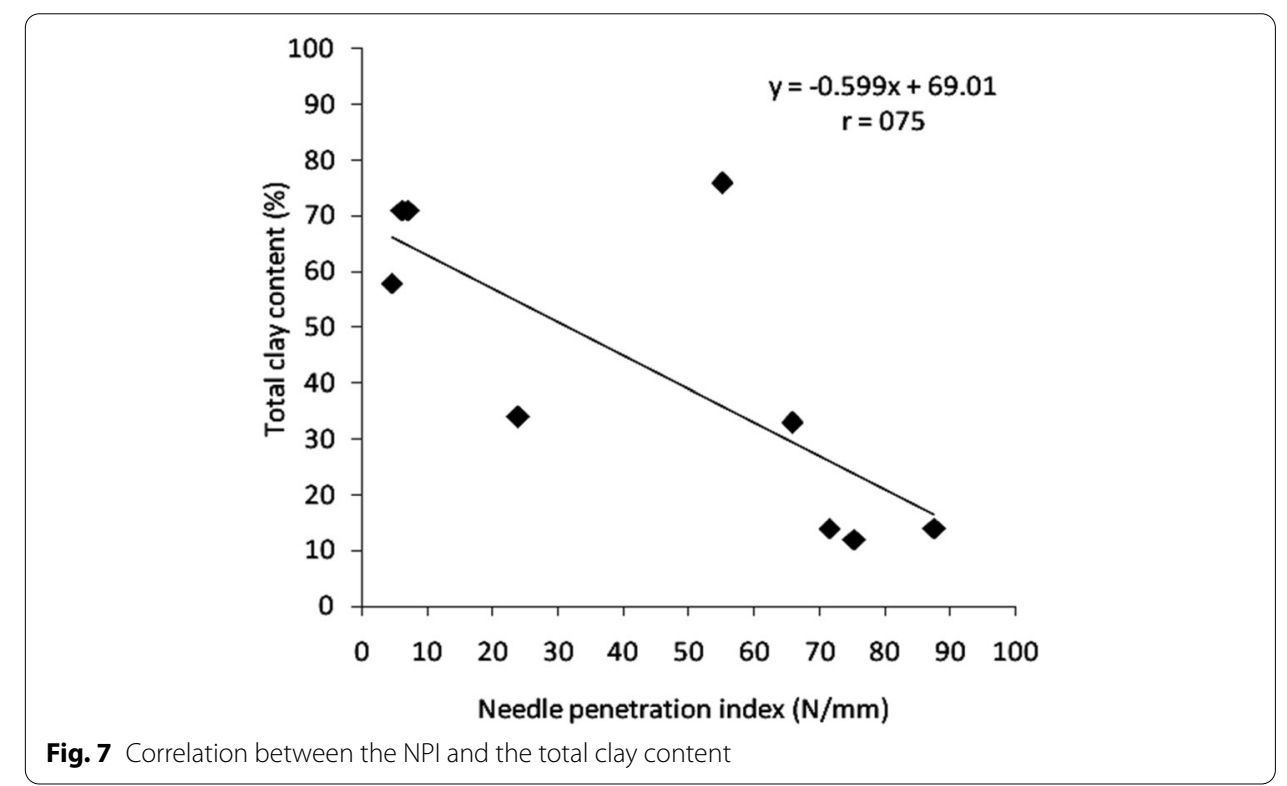

Aydan [6] demonstrated that the conversion factor for the UCS-NPI relation ranges between 0.06 and 0.70 and most of the data points were clustered around the empirical function with a coefficient of 0.20 . In this study, the conversion factor was 0.35 , as shown in Eq. (17), which is fairly close to 0.20 . In order to make a visual comparison, Eqs. (7), (8), and (17) were plotted graphically, as shown in Fig. 6. All the equations show a similar trend, but there are some differences among them. The function derived in this study is almost the same as the function derived by Ulusay and Erguler [13].

Although the correlation between the UCS and the NPI is strong, some of the data points were scattered. It is thought that one of the reasons behind the scattered data points may be the different clay contents of the tested rocks. For this reason, the correlations between the clay contents and the NPI were investigated. 


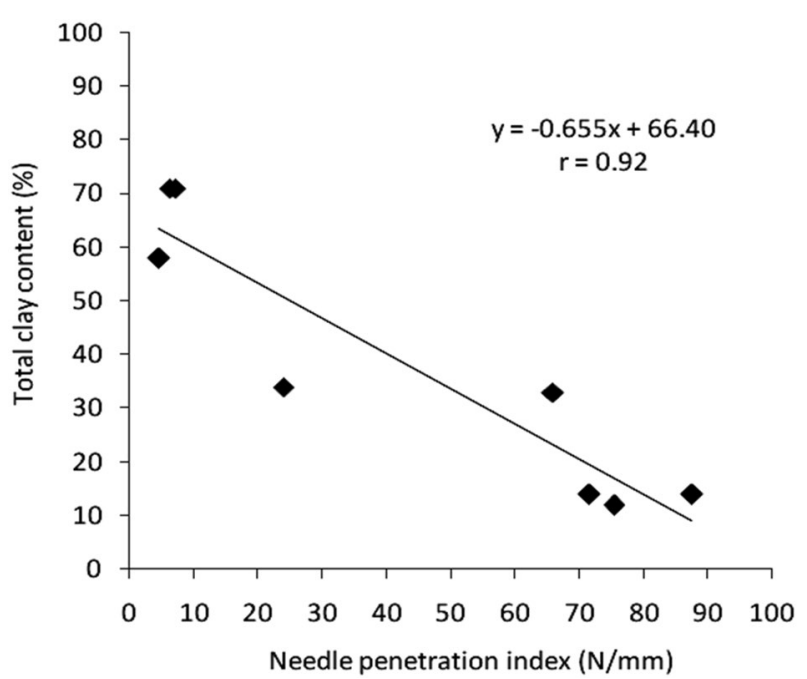

Fig. 8 Correlation between the NPI and the total clay content excluding the data point of location E 209-104 m

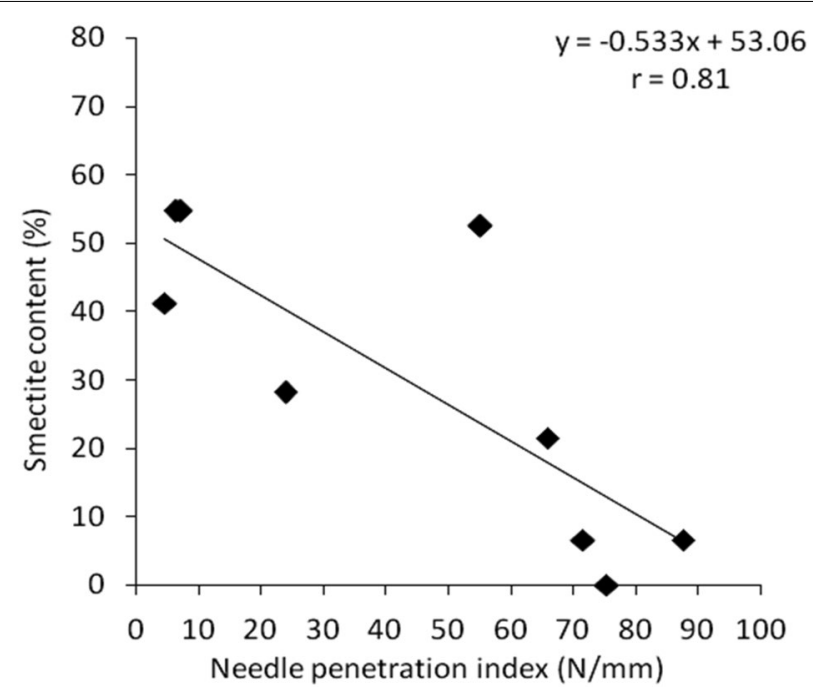

Fig. 9 Correlation between the NPI and smectite content

The NPI values were correlated to the total clay content, smectite content, and the total of illite and kaolinite content, respectively. Because four samples have small amount of kaolinite content, illite and kaolinite minerals were evaluated together. There is a good correlation between the NPI and the total clay content, as indicated in Fig. 7. However, the data point of location E 209-104 m indicates anomaly. This is probably due to the fact that the sample of this location includes high quartz and feldspar contents and an unknown quantity of siderite compared to the similar samples. These minerals have high hardness and increase the NPI values. When the correlation graph is re-plotted excluding the outlying data point, the correlation coefficient significantly increases (Fig. 8). 


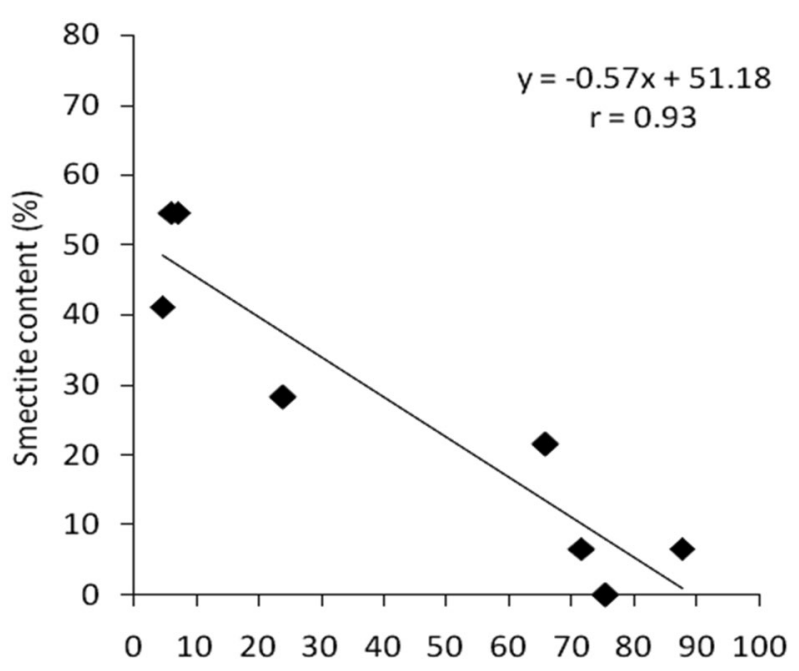

Needle penetration index $(\mathrm{N} / \mathrm{mm})$

Fig. 10 Correlation between the NPI and smectite content excluding the data point of location E 209-104 m

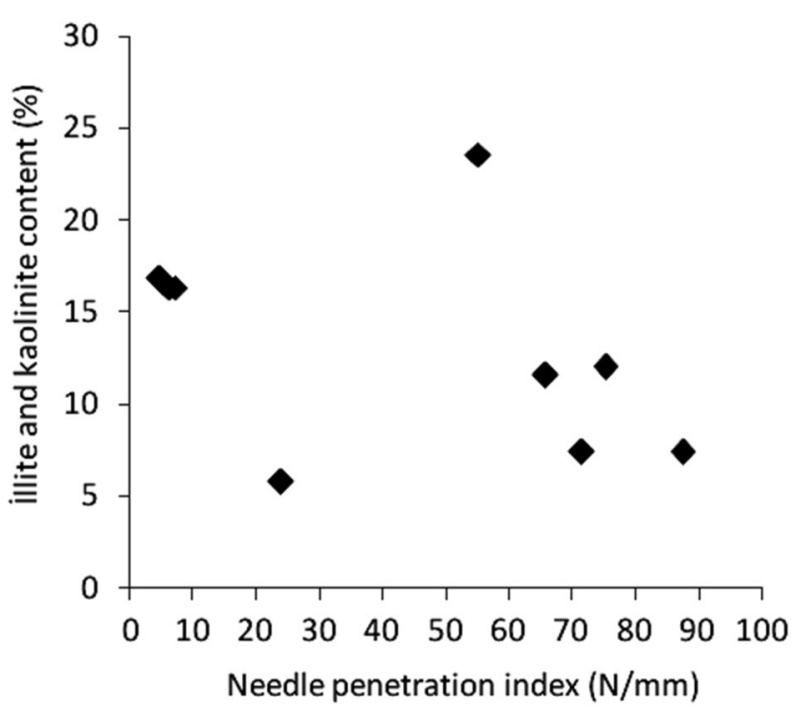

Fig. 11 Correlation between the NPI and the total illite and kaolinite content

The correlation between the NPI and the smectite content is good (Fig. 9). The data point of location E 209-104 m also indicates anomaly in this correlation plot. As shown in Fig. 10, the correlation coefficient significantly increases $w$ hen the correlation graph is re-plotted excluding the outlying data point.

There is no correlation between the NPI, and the total content of illite and kaolinite for the tested rocks as indicated in Fig. 11. It can be said that there is no effect of the total illite and kaolinite content on the NPI.

The correlations between the clay contents and the UCS were also investigated. As shown in Fig. 12, a very strong logarithmic correlation was found between the UCS and total clay content. Increasing the clay content decreases the UCS. Smectite 


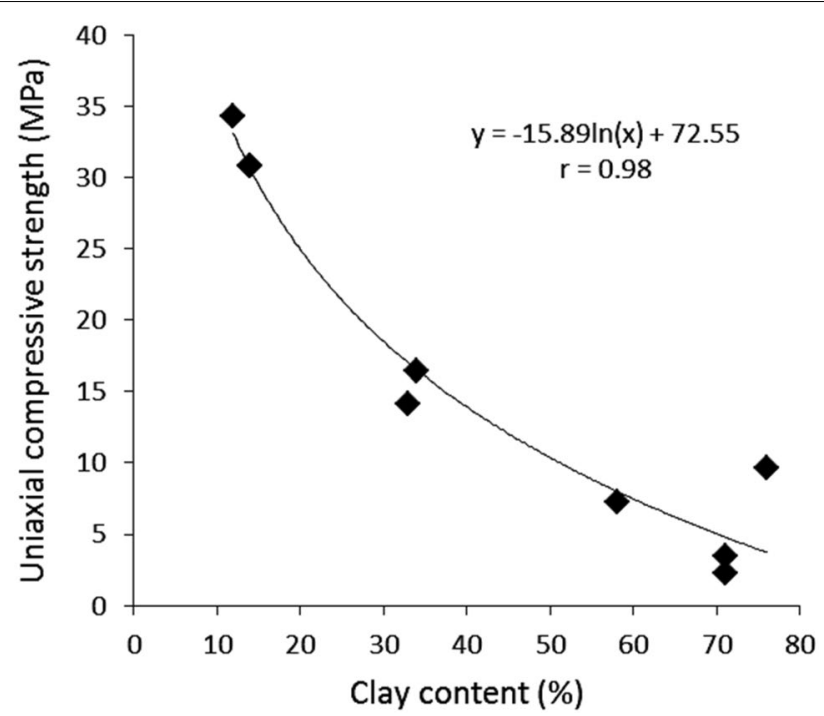

Fig. 12 Correlation between the UCS and the total clay content

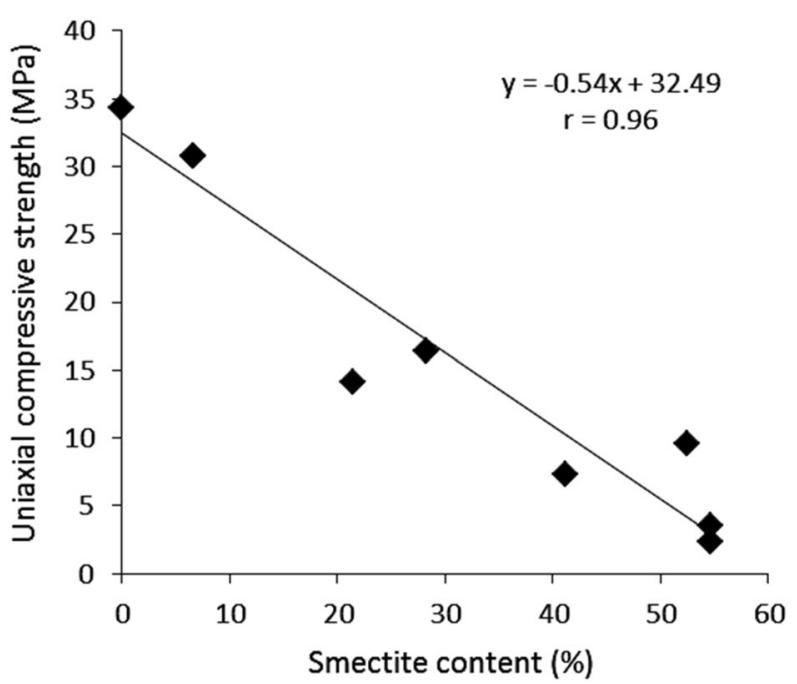

Fig. 13 Correlation between the UCS and smectite content

content was also strongly correlated to the UCS (Fig. 13). The correlation between the two parameters follows an inverse linear function. The total illite and kaolinite content was poorly correlated to the UCS. The correlation coefficient of this relation is weak, as shown in Fig. 14.

Previous studies also revealed that the strength of rocks decreases with the increasing clay content [23-25]. That the clays reduce the strength of rocks is explained by three mechanisms: (1) The clay content in the quartz-clay framework can directly decrease the friction resistance of the rock by reducing the grain contacts of the original interconnected quartz grains. (2) The crystalline swelling and the surface hydration explain the main changes of the mechanical properties when getting saturated. 


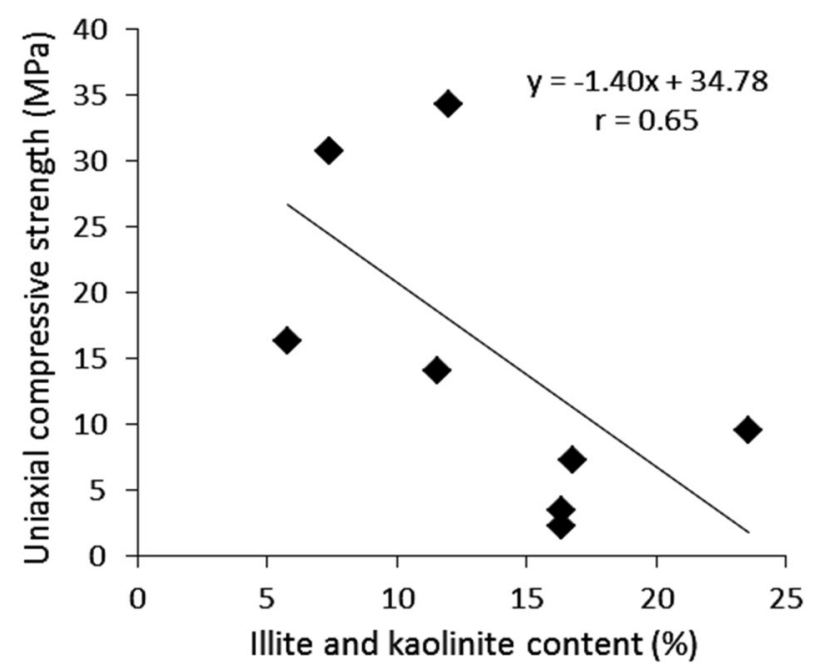

Fig. 14 Correlation between the UCS and the total illite and kaolinite content

(3) Although the clay cement and coating to the framework of grains can help improve the resistance of rock to the applied stress, such a clay-binding among grains is still weaker than the cohesion strength of grains and that of quartz overgrowths [25].

It is clear that clay content, especially smectite content, has strong effect on the NPI and UCS in clay-bearing rocks. Therefore, it can be said that clay content may influence the UCS-NPI relation. The multiple regression analysis was carried out in order to observe the effect of clay content on the UCS-NPI relation. The derived model is as follows:

$$
U C S=0.12 N P I-0.32 C C+24.7 \quad \mathrm{r}=0.96
$$

where UCS is the uniaxial compressive strength (MPa), NPI is the needle penetration index $(\mathrm{N} / \mathrm{mm})$, and CC is the total clay content (\%).

Equation (18) has a very strong correlation coefficient. Inclusion of the total clay content to the regression analysis increased the correlation coefficient from 0.84 (for Eq. 17) to 0.96 . This shows that clay content significantly influences the UCS-NPI relation in clay-bearing rocks.

Equation (9) have a very strong correlation coefficient. But, the strong correlation coefficient may not always indicate a valid model. Student test (t-test) and F-test are the common statistical tests performed for the validation of the regression equations. For carrying out the $\mathrm{t}$-test, the variables should indicate normal distribution. The histogram analysis shows that the UCS and the NPI values have non-normal distribution as shown in Figs. 15 and 16. Therefore, t-test was not performed.

The analysis of variance may be used to check the significance of regressions. The confidence levels were chosen as $95 \%$ in the analysis. In the F-test, when the test values of F-ratios are greater than the critical F-ratio found in the standard table, the null hypothesis is rejected, suggesting an actual correlation is found between the two variables. The test value of the F-ratio is 36.46 and the critical F-ratio is 5.59. Because the test F-ratio is greater than the critical F-ratio, the Eq. (9) is valid. 


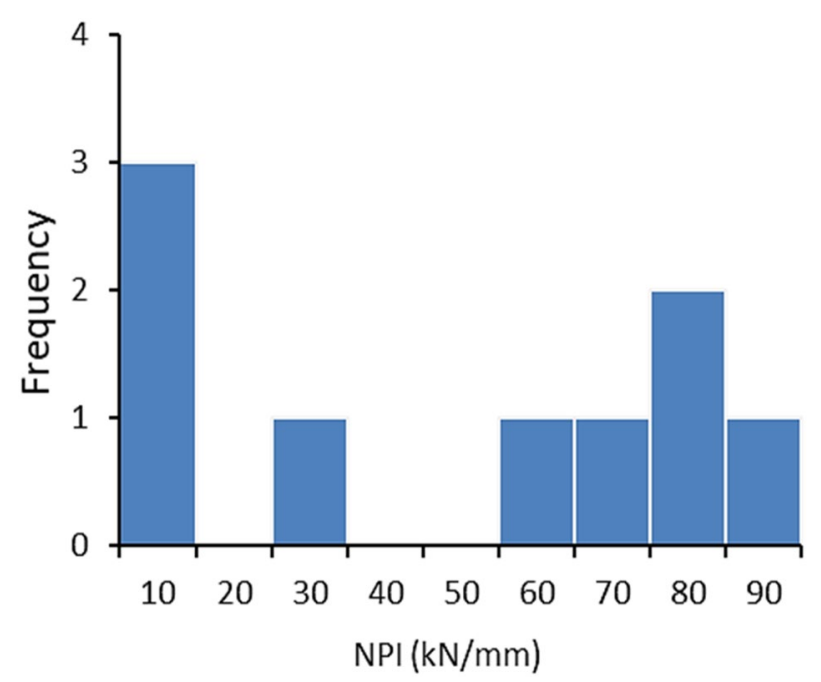

Fig. 15 Histogram plot for the NPI values

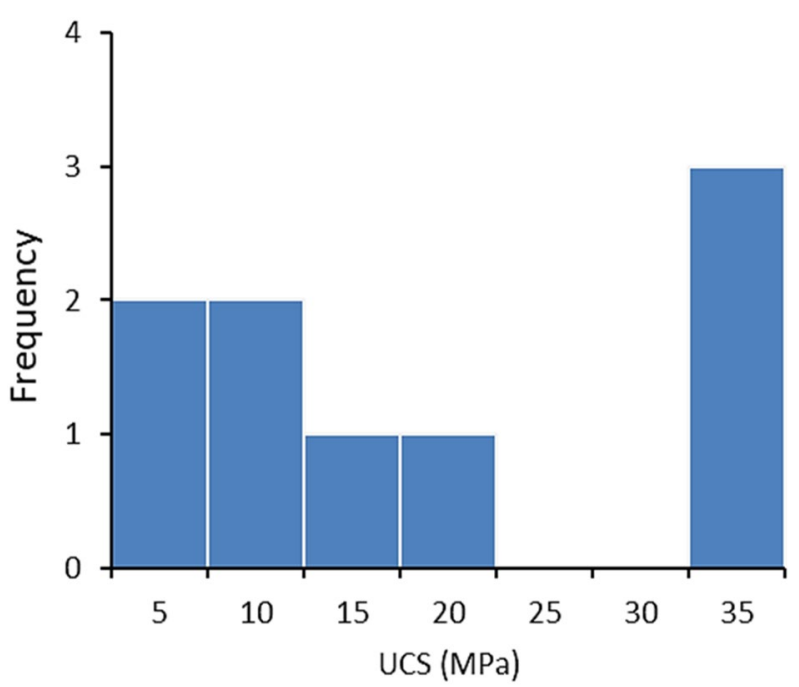

Fig. 16 Histogram plot for the UCS values

\section{Conclusion}

The needle penetration index (NPI) tests were performed at different gallery faces in a coal mine, and block samples of clay-bearing rocks were collected to determine of the uniaxial compressive strength (UCS) and clay contents. The NPI, UCS, and the clay contents were evaluated to demonstrate the effect of clay content on the UCS-NPI relation. It was observed that, although a strong correlation was found between the UCS and the NPI, some of the data points were scattered. Both the NPI and the UCS values were also strongly correlated to the total clay content and the smectite content. A multiple regression model was derived for the estimation of the UCS from the NPI and the clay content. This model has a very strong correlation coefficient, which is comparatively higher than that of the UCS-NPI relation derived using simple regression analysis. It can be concluded that clay content can significantly influence the UCS-NPI relation in clay-bearing rocks. 


\section{Acknowledgements}

The authors thank TUBITAK (The Scientific and Technological Research Council of Turkey) for supporting the project (Project No. 114M836). The authors also thank the CINER Group for allowing field studies.

\section{Authors' contributions}

SK organized the field and laboratory studies and wrote the paper. ASA performed field studies. ES carried out laboratory studies. BA carried out laboratory studies. All authors read and approved the final manuscript.

\section{Competing interests}

The authors declare that they have no competing interests.

\section{Author details}

${ }^{1}$ Mining Engineering Department, Hacettepe University, Ankara, Turkey. ${ }^{2}$ CINER Group, Ankara, Turkey.

Received: 2 January 2019 Accepted: 24 November 2020

Published online: 27 February 2021

\section{References}

1. Ulusay R, Aydan O, Erguler ZA, Ngan-Tillard DJM, Seiki T, Verwaal W, Sasaki Y, Sato A (2014) ISRM suggested method for the needle penetration test. Rock Mech Rock Eng 47:1073-1085

2. Yamaguchi Y, Ogawa N, Kawasaki M, Nakamura A (1997) Evaluation of seepage failure response potential of dam foundation with simplified tests. J Jpn Soc Eng Geol 38(3):130-144

3. Aydan O, Watanabe S, Tokashiki N (2008) The inference of mechanical properties of rocks from penetration tests. In: Proc. of the 5th Asian Rock Mechanics Symposium (ARMS5), Tehran, pp 213-220

4. Erguler ZA, Ulusay R (2007) Estimation of uniaxial compressive strength of clay-bearing weak rocks using needle penetration response. In: Proc. of 11th Congress on International Society for Rock Mechanics, Lisbon, pp 265-268

5. Park Y, Obara Y, Kan SS (2011) Estimation of uniaxial compressive strength of weak rocks using needle penetrometer. In: Proc. of 12th ISRM International Congress on Rock Mechanics, Beijing, pp 795-798

6. Aydan O (2012) The inference of physico-mechanical properties of soft rocks and the evaluation of the effect of water content and weathering on their mechanical properties from needle penetration tests. In: Symposium of ARMA, Chicago, Paper No. ARMA12-639 (on CD)

7. Aydan O, Ulusay R (2013) Geomechanical evaluation of Derinkuyu antique underground city and its implications in geoengineering. Rock Mech Rock Eng 46:731-754

8. Aydan O, Sato A, Yagi M (2014) The inference of geo-mechanical properties of soft rocks and their degradation from needle penetration tests. Rock Mech Rock Eng 47:1867-1890

9. JSCE-RMC (1980) A suggested method for investigation and testing of soft rocks. In: Japan Society of Civil Engineers, Rock Mechanics Committee, The 4th Sub-committee, Tokyo (in Japanese)

10. Okada S, Izumiya Y, lizuka Y, Horiuchi S (1985) The estimation of soft rock strength around a tunnel by needle penetration test. J Jpn Soc Soil Mech Found Eng 33(2):35-38 (in Japanese)

11. Takahashi K, Noto K, Yokokawa I (1988) Strength characteristics of Kobe formation in Akashi Strata (No. 1). In: Proc. of 10th Japan National Conference on Geotechnical Engineering, Tokyo, pp 1231-1232 (in Japanese)

12. Uchida N, Etoh Y, Ono H, Miura N (2004) Strength evaluation of deep mixing soil-cement by needle penetration test. J Jpn Soc Soil Mech Found Eng 52(7):23-25 (in Japanese)

13. Ulusay R, Erguler ZA (2012) Needle penetration test: evaluation of its performance and possible uses in predicting strength of weak and soft rocks. Eng Geol 149-150:47-56

14. Takahashi K, Noto K, Yokokawa I (1988) Strength characteristics of Kobe formation in Akashi Strata (No. 1). In: Proc. of 10th Japan National Conf. on Geotech. Eng., The Japanese Geotechnical Society, pp 1231-1232 (in Japanese)

15. Maruto Co. Ltd., (2006) Penetrometer for Soft Rock: Model SH-70 Instruction Manual. Tokyo, Japan

16. Kahraman S, Yumsak SM, Koyuncu YA (2016) The predictability of physico-mechanical properties of pyroclastic rocks from the needle penetration index. In: 50th US Rock Mechanics/Geomechanics Symposium, Houston, USA, 26-29 June 2016, Paper No. ARMA16-809 (on CD)

17. Kahraman S, Aloglu AS, Aydin B, Saygin E (2017) The needle penetration test to predict the coal strength. J Southern Afr Inst Min Metall 117:587-591

18. Heidari M, Mohseni H, Jalali SH (2017) Reliability assessment of needle penetration index for estimating compressive strength of some sedimentary rocks from the Qom Formation. Central Iran Geopersia 7(1):103-116

19. Rahimi MR, Mohammadi SD, Heidari M, Jalali SH (2020) Evaluation of the needle penetration test to estimate the uniaxial compressive strength of gypsum rocks. Arab J Geosci 13:14

20. Haciosmanoglu ME (2004) Development of a subsidence model for Cayirhan coal mine, MSc. Thesis, Middle East Technical University, Turkey

21. Aydın Y, FunfstuckJ (1988) Beypazari Project Report. In: Proc. of the Sixth Coal Congress of Turkey, Zonguldak, pp 53-71 (in Turkish)

22. ISRM (1985) Suggested method for determining point load strength. Int J Rock Mech Min Sci Geomech Abstr 22:51-60

23. Jizba DL (1991) Mechanical and Acoustical Properties of Sandstones and Shales. PhD thesis. Stanford University, USA.

24. Kohno M, Takehara Y, Nishimura T (2018) Effect of structure of clay mineral on the physical and mechanical properties of rock materials. J Soc Mater Sci, Japan 67(3):324-329

25. He W, Chena K, Hayatdavoudi A, Sawant K, Lomas M (2019) Effects of clay content, cement and mineral composition characteristics on sandstone rock strength and deformability behaviors. J Petrol Sci Eng 176:962-969

\section{Publisher's Note}

Springer Nature remains neutral with regard to jurisdictional claims in published maps and institutional affiliations. 